A PAISAGEM DE SÃO SALVADOR DO CONGO E O DISCURSO COLONIAL PORTUGUÊS FRENTE A CONFERÊNCIA DE BERLIM (1884-1885)

THE LANDSCAPE OF SAN SALVADOR DE CONGO AND THE PORTUGUESE COLONIAL DISCOURSE IN THE BERLIN CONFERENCE (1884-1885)

Bruno Pastre Máximo

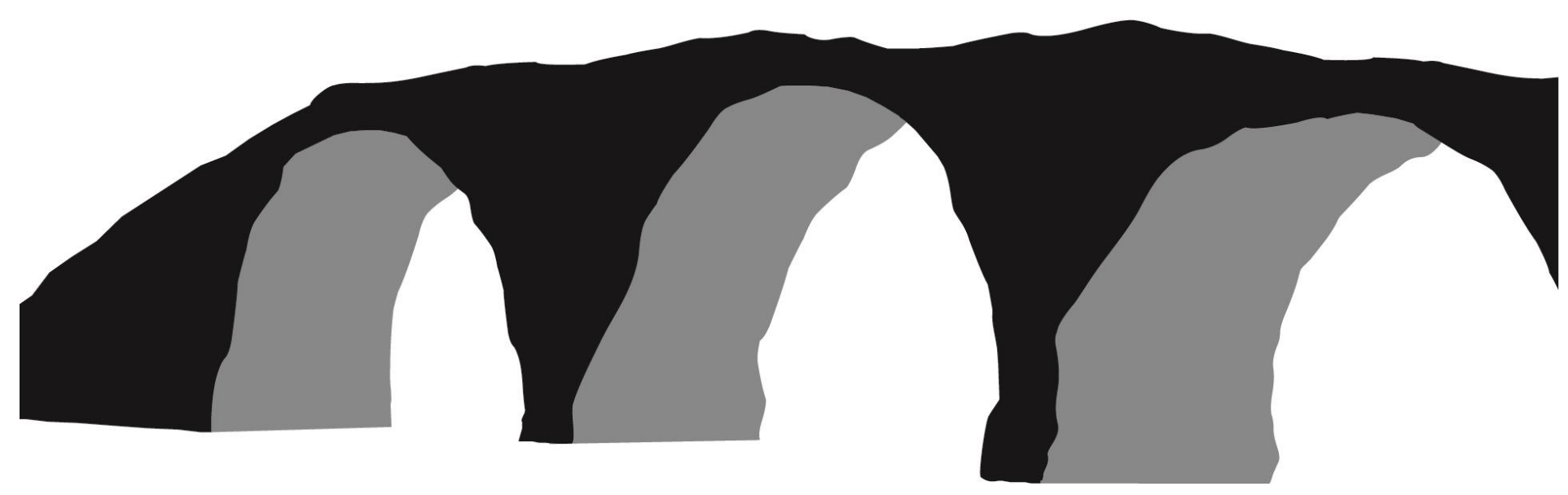




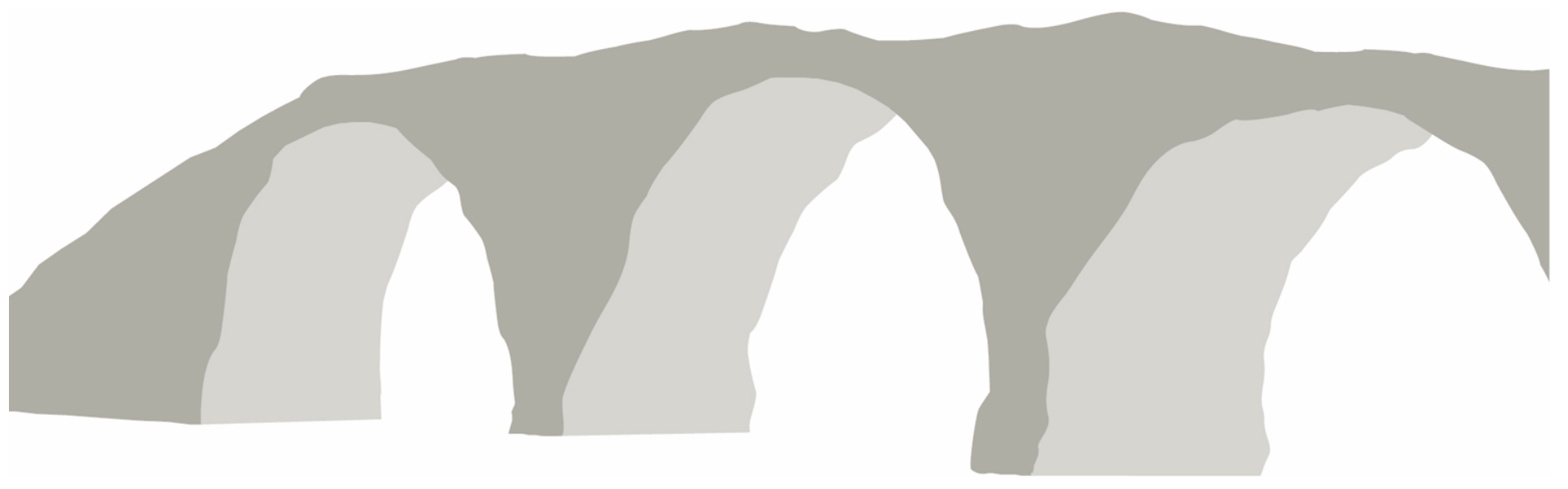

Data de recebimento: 29/08/2017.

Data de aceite: 28/05/2018. 


\title{
A PAISAGEM DE SÃO SALVADOR DO CONGO E O DISCURSO COLONIAL PORTUGUÊS FRENTE A CONFERÊNCIA DE BERLIM (1884-1885)
}

\section{THE LANDSCAPE OF SAN SALVADOR DE CONGO AND THE PORTUGUESE COLONIAL DISCOURSE IN THE BERLIN CONFERENCE (1884-1885)}

\author{
Bruno Pastre Máximo ${ }^{1}$
}

\begin{abstract}
RESUMO
Este artigo busca compreender e analisar o papel da paisagem colonial portuguesa da cidade de São Salvador do Congo nas disputas envolvendo a partilha da África no final do século XIX. A cidade de São Salvador do Congo, atualmente chamada de Mbanza Kongo (Angola), esteve no centro da argumentação colonial portuguesa, considerando principalmente os vestígios arqueológicos e os seus lugares de poder, que atestavam e legitimavam a presença e domínio do território na margem sul do rio Congo. Assim, através da análise das narrativas coloniais, identifica-se a configuração da paisagem colonial lusitana, uma paisagem declamada de glórias e feitos notáveis, diretamente relacionada com o domínio sociopolítico e religioso do Reino do Kongo.
\end{abstract}

Palavras-chave: São Salvador do Congo, história de Angola, partilha da África, paisagem colonial portuguesa, Mbanza Kongo.

\section{RESUMEN}

Este artículo busca comprender y analizar el papel del paisaje colonial portugués de la ciudad de San Salvador del Congo en las disputas involucrando el reparto de África a finales del siglo XIX. La ciudad de San Salvador del Congo, actualmente llamada Mbanza Kongo (Angola), estuvo en el centro de la argumentación colonial portuguesa, considerando principalmente los vestigios arqueológicos y sus lugares de poder, que atestaban y legitimaban la presencia y dominio del territorio en la margen sur del río Congo. Através del análisis de las narraciones coloniales, se identifica la configuración del paisaje colonial lusitana, un paisaje de gloria y hechos notables, directamente relacionada con el dominio socio-político y religioso del Reino de Kongo.

Palabras clave: São Salvador del Congo, história de Angola, reparto de África, paisaje colonial portuguesa, Mbanza Kongo.

\footnotetext{
${ }^{1}$ Mestre em Arqueologia pelo MAE/USP. Doutorando em Antropologia, com concentração em Arqueologia pelo PPGAN/UFMG. Técnico de Laboratório em Arqueologia, Universidade Federal dos Vales do Jequitinhonha e Mucuri (UFVJM). Laboratório de

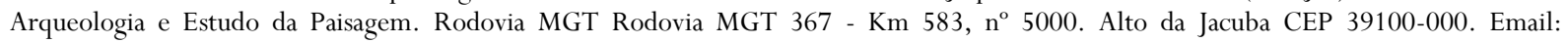
pastrebruno@gmail.com.
} 


\begin{abstract}
This article seeks to understand and analyze the role of the Portuguese colonial landscape of the city of San Salvador of Congo in the disputes involving the scramble of Africa in the late nineteenth century. The city of São Salvador de Congo, currently called Mbanza Kongo (Angola), was in the center of the Portuguese colonial narrative, due to the significance of its archaeological remains and places of power. These places legitimized the control over the territory on the southern margin of the Congo river. The configuration of the colonial landscape is approached through the analysis of the Portuguese narratives. This was a landscape fulfilled with outstanding achievements, which are related with the social, political and religious domain of the Kongo Kingdom.
\end{abstract}

Keywords: São Salvador do Congo, Angola history, scramble of Africa, portuguese colonial landscape, Mbanza Kongo. 
As interpretações relacionadas com o passado histórico do reino do Kongo (Figura 1) e a presença portuguesa na região norte de Angola feitas por autores colonialistas portugueses no século XIX, buscavam legitimar as possessões portuguesas na África centro-ocidental, dando sustentação para a argumentação jurídica dos “direitos de possessão históricos”. O objetivo principal das pesquisas era que a história da região se adaptasse aos interesses políticos coloniais.

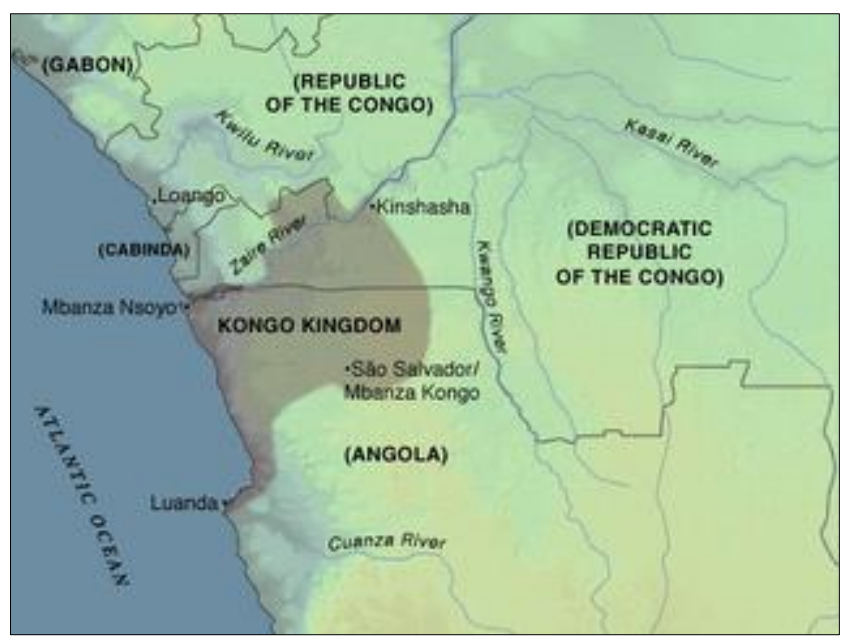

Figura 1: Mapa do Reino do Kongo mostrando sua extensão em torno do ano 1800. https://web.archive.org/web/20130305121935/http://www.kongoking.org/. Acesso em 10/16/2018

Nesse contexto, este artigo busca entender o papel da cidade de São Salvador do Congo (atual Mbanza Kongo) dentro do que chamamos paisagem colonial portuguesa no norte de Angola, tomando como base a análise da narrativa colonial sobre legitimidade da ocupação lusitana na região. A paisagem que identificamos na narrativa colonial é a paisagem definida pelos lugares construídos - construída por marcos referenciais e simbólicos em que são projetados mitos e ideologias, que, não raramente, vêm para congelar seu significado de si mesmas na contemporaneidade (Knapp \& Ashmore, 1999).

Para podermos entender o processo de consolidação da colonização portuguesa no norte de Angola, devemos lembrar que, até o ano de 1846, o interesse de Portugal e das outras potências pela posse administrativa da região compreendida como Reino do Kongo era praticamente nulo (Marques, 2006). Do início do século XIX até 1845, nenhum viajante europeu esteve em São Salvador do Congo ou nos arredores, contrariando a massiva presença militar e missionária dos séculos anteriores, amplamente estudada pela historiografia e com muitas fontes primárias e secundárias (Hilton, 1985; Souza, 2002; Thornton, 1983; Cavazzi Montecuccolo, 1965; Pigafetta \& Lopes, 1989; Brásio, 1952). Toda presença europeia na zona do baixo rio Congo em meados do século XIX se resumia a uma atividade comercial que se concentrava na zona das margens do rio Congo, nas regiões de Banana e Porto Lenha e no Ambriz - ambas regiões exportadoras de escravos - e, que se encontravam fora de qualquer jurisdição administrativa europeia (Marques, 2006; Tuckey, 1818).

Baseando-se em sua política de policiar o Atlântico e terminar com o tráfico de escravos, o Reino Unido negociava, desde o começo do século XIX, com Portugal para que se extinguisse o tráfico transatlântico. Portugal, sabendo das grandes implicações econômicas na vida da colônia de Angola, buscou ao máximo 
protelar o término deste infame comércio, como explica Marques (2006; p. 149): “(...) todos os governadores [de Angola] tinham perante si uma dificuldade incontornável: se incrementassem a supressão do tráfico negreiro dignificariam a nação, mas arruinariam as finanças locais." Como forma mais incisiva de ação na região, em 1846, os britânicos, visando coibir as pretensões portuguesas de conquista do norte de Angola, e a consequente taxação alfandegária, interferiram diretamente nesta região, não reconhecendo os direitos portugueses de posse acima do rio Loge (Marques, 2006).

Essa negação de soberania lusa pelos ingleses marcou uma redefinição dos interesses portugueses em Angola, aumentando os estudos sobre a região (Lima, 1845; Sarmento, 1880; Santarém, 1855; Cruz, 1858, 1859; Castro, 1880) e dando origem a uma série de movimentos contrários a tal imposição, que culminaram em um grande volume de publicações e tratados, e, por fim, na própria conferência de Berlim. Nesse contexto, a Sociedade de Geografia de Lisboa, fundada em 1875, tornou-se o centro do pensamento colonial português, ao congregar e publicar os principais trabalhos sobre as colônias. Quando nos referirmos aos portugueses neste momento, falamos principalmente dessa elite intelectual com um plano colonial definido, pois, como veremos a seguir, para o resto da população de Portugal, e mesmo para a de Luanda, o norte do Ambriz era um lugar desconhecido.

São Salvador e todos os outros lugares significativos para os portugueses se consolidaram como paisagem ao norte de Angola frente à negação britânica, e foi a partir deste movimento que Ambriz foi ocupado pelo exército lusitano em 1855, o Bembe em 1856 e S. Salvador em 1858, com o objetivo de mostrar e marcar presença na região. Devemos entender essa formação de paisagem de acordo com os preceitos jurídicos que norteavam o pensamento de legitimidade do direito Português aplicado ao europeu e com o momento histórico de conflitos imperialistas, que iriam culminar na partilha da África.

Segundo Luciano Cordeiro (1883: 33), a legitimidade de um território podia ser atestada:

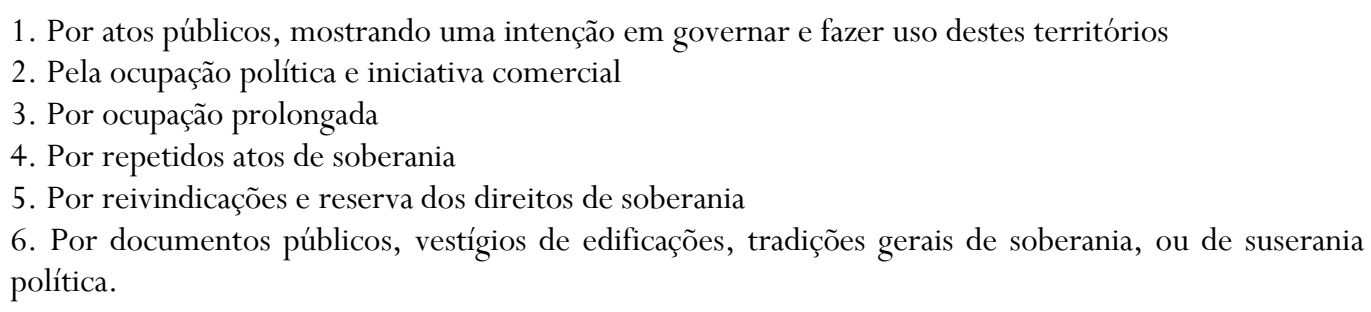

Por isso, a partir dessas ideias, a história de Portugal com o Reino do Kongo foi explorada pela Sociedade de Geografia de Lisboa de forma sistemática para sustentar todos estes pontos, e as teses consolidadas do pensamento colonial foram compiladas em um livro de autoria da Sociedade, chamado Memorandum: A questão do Zaire e os Direitos de Portugal, de 1883, que passou a servir como elemento final de análise.

Subscrevendo ao escopo deste texto, procuraremos demonstrar o papel da cidade de São Salvador na argumentação colonial, compreendendo em especial a sexta categoria. Faremos também um balanço sobre a produção bibliográfica portuguesa sobre a cidade, apontando importantes debates e contrapontos com autores ingleses, com a finalidade de apresentar diferentes perspectivas da cidade no século XIX e como elas foram apropriadas no discurso colonial português para sua legitimação frente as outras potências, terminadas com a conferência de Berlim (1884-1885). 


\section{PRODUÇÃo BIBLIOGRÁFICA SOBRE SÃo SALVADOR DO CONGO EM MEADOS DO SÉCULO XIX - CONTRASTE ENTRE A PRODUÇ̃̃O PORTUGUESA E BRITÂNICA}

É certo que ao indivíduo que pela primeira vez chega ao Congo e vê esta povoação situada num magnífico planalto, que domina quasi todos os montes que a cercam, possuindo nos seus flancos abundâncias de nascentes, d'onde jorra agua egual a melhor da Europa, se affigura que está num eden onde não pode entrar a venenosa serpente das febres intermittentes; é um erro, se aqui se demorar, conhecerá por dolorosa experiência que foi precipitado no seu juízo ${ }^{2}$.

No período que compreende o final do século XVIII até os finais do século XIX os portugueses estiveram na cidade de São Salvador de forma muito esparsa. Nesse período se aprofundaram as disputas políticas internas, enfraquecendo o poder político dos monarcas e os deixando com cada vez menos territórios controlados diretamente, ainda que mantivessem seu prestígio.

A primeira publicação sobre a cidade que possuímos do século XIX é a do Capitão Castro, de 1845. Nela é expresso que a sua expedição tinha como objetivo reatar as relações entre o Rei do Kongo e os portugueses de Luanda, através de tratados que envolviam favores comerciais, políticos e religiosos. As dificuldades eram enormes. Segundo o autor, não existiam rotas para a cidade neste período:

Para esta viagem não pude colher informações nenhuma em Luanda, parecendo assim que era um caminho encetado de novo, e um único itinerário que existia, e que foi feito por mim quando chefe da repartição militar na província de Angola, esse mesmo estava muito errado por não ter obtido boas informações; tive pois de fazer esta viagem como puramente nova (CASTRO, 1880). ${ }^{3}$

A falta de rotas deixa claro que as relações entre S. Salvador e Luanda não eram das mais intensas. Poucos brancos iam à cidade. Segundo Barroso (1888-1889: 168), “[...] os europeus não vão para estes lados [S. Salvador], (...) e o rei que tinha, (...) para mais de setenta anos, e outros ainda mais velhos que ele, fui eu o primeiro homem branco que viram a não ser os ditos frades [barbadinhos]”. Para Luanda neste momento, S. Salvador era um mapa "em branco" ao norte de Angola, como fica evidente no mapa produzido por Lima de 1846 (Figura 2). Não havia interesse comercial, e todas atenções estavam centradas em outras regiões que outrora estiveram sob domínio do Rei do Kongo - o Bembe (Monteiro, 1876) e, principalmente, o Ambriz, importante centro comercial - e no centro-sul de Angola (Pelissier, 1986). Se um capitão rumo a S. Salvador não conseguiu colher informações sobre o caminho e a cidade, concluímos que as relações estavam desaparecidas, muito distantes das que foram nos séculos passados, com as informações provavelmente “perdidas" nos arquivos e bibliotecas. Até então, S. Salvador era um lugar desconhecido e aparentemente irrelevante para os portugueses. Isto até 1846.

\footnotetext{
${ }^{2}$ Viagem ao Bembe do Cônego Antônio Barroso. Documento n ${ }^{\circ} 1$ anexo ao ofício n ${ }^{\circ}$ 493: relatório da viagem ao Bembe do cônego Antônio José de Sousa Barroso. In: Oliveira \& Couto, 1971: 446.

${ }^{3}$ Sem paginação disponível por ter sido consultado a versão eletrônica.
} 


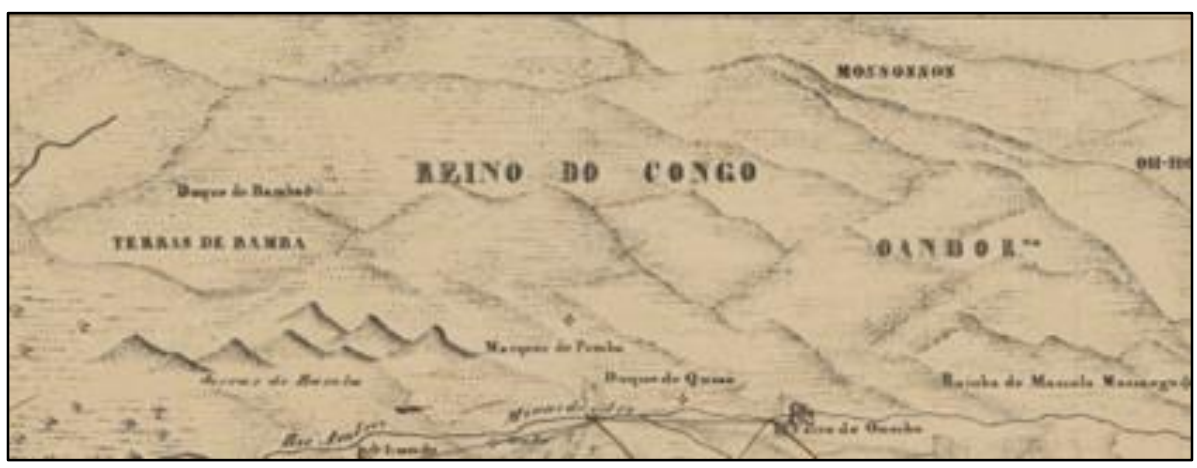

Figura. 2: Detalhe do Reino do Congo. Fonte: Carta Geographica dos Reinos de Angola e Benguela. Feito por José Joaquim Lopes de Lima, 1846. In:

https: / / web.archive.org/web/20161113170956/http: / / catalog.afriterra.org/viewMap.cmd?number=321

O cartógrafo responsável pela confecção deste mapa (Figura 2) foi José Joaquim Lopes de Lima, que também foi o primeiro autor consultado a publicar um trabalho historiográfico sobre o Reino do Kongo (Lima, 1845). Podemos, assim, destacar os anos de 1845-46 como marco das relações entre Luanda e São Salvador, representado pelo primeiro livro de história, mapa e expedição diplomática do século XIX. Em 1856, ainda no reinado de Henrique II, o português Alfredo Sarmento visitou o Reino do Kongo, e deixou também uma descrição de S. Salvador, os usos e costumes da cidade (Sarmento, 1880). Seu objetivo com a missão era continuar os acordos e diplomacia iniciados em 1845, levando um pároco, presentes e cartas de Luanda à cidade. Após a visita de Sarmento, outro autor a publicar sobre a cidade foi o chefe do recém-criado conselho de D. Pedro V (Bembe), o Tenente Zacharias da Silva Cruz, que, entre 1858-1859, publicou um relatório sobre sua ida a S. Salvador e sobre o confronto militar que surgiu após a morte de Henrique II.

As publicações de Castro, Sarmento e Zacharias, no entanto, não alcançaram o grande público, sendo limitadas a uma tiragem pequena e com circulação restrita, limitando seu acesso até mesmo para o público português. Por outro lado, um texto que obteve algum destaque internacional foi o do famoso etnógrafo alemão Adolph Bastian, que esteve na cidade em 1857 fazendo pesquisas junto à monarquia sobre a cultura Kongo (Bastian, 1859) ${ }^{4}$. O seu trabalho foi referencial para os não lusófonos interessados no Reino do Kongo. Autores como Johnston (1910: 75) e Stanley (1885: 13; 1878: 359) afirmaram em suas obras a importância de Bastian e ignoraram os autores portugueses:

O reino do Kongo de São Salvador não foi revisitado por Europeus até 1857, quando o explorador Alemão, Dr. Bastian, fez seu caminho para a capital.

Então segue um silêncio e um branco na história da terra-Congo, e a ruína reclama uma outrora promissora cidade catedral por si própria. Nós não escutamos mais nada até Dr. Bastian, um eminente viajante Alemão, após explorar naquela localidade em 1857[...].

[...] Dr. Bastian escreve em 1857 que [São Salvador] é somente 'uma cidade nativa ordinária, com alguns poucos monumentos espalhados de outros dias.

Ainda, Johnston e Stanley afirmam que, nos primeiros anos do século XIX, o reino do Kongo foi "abandonado" pelos “europeus”, desconsiderando a presença portuguesa e reconhecendo somente aqueles que

\footnotetext{
${ }^{4}$ Infelizmente não nos foi possível a leitura desta obra, por estar em alemão e não existir versão traduzida. Pequenos trechos da obra citada se encontram traduzidos na monumental obra de Beatrix Heintze (2010). Da vasta obra do autor, pouco foi comentado sobre o seu trabalho na cidade de São Salvador do Congo, o que nos impede de uma análise secundária.
} 
escreveram e publicaram em meios cientificamente legítimos e abrangentes - como Bastian. Nessa obra eles não consideraram os outros portugueses que continuavam a frequentar a região, sejam como oficiais ou comerciantes de escravos. Bastian, já na condição de cientista, revelou ao mundo o Reino do Kongo no século XIX - classificando-a, nas palavras de Stanley, como "uma cidade ordinária”. Ordinária em um sentido europeu e etnocêntrico, tomando como referencias os seus valores do que deveria ser uma capital de um Estado. Mesmo para os europeus, se por um lado a cidade era comum, por outro era sede da Monarquia do Kongo, internacionalmente legítima sobre um território que outrora fora enorme.

Em meados do século XIX essa evidência da cidade seria então alçada pelo mais popular nome das explorações africanas, Dr. Livingstone. Mesmo não passando pela cidade, fez uma breve menção que iria mudar a história da região. Em 1857, ele escreveu (Livingstone, 1861:426-427):

Eu fui informado, no que parecia boa fonte, que o Príncipe do Congo [Nicolau de Água Rosada] é um cristão professo, e que há não menos que doze igrejas neste reino [Kongo], os frutos da missão estabelecida em tempos antigos em São Salvador, a capital. Estas igrejas são mantidas em reparo parcial pelas pessoas, que também mantém a cerimônias da Igreja, pronunciando algumas ladaínhas sobre os mortos, imitando as rezas Latinas nos quais eles escutaram antigamente. Muitos deles podem ler e escrever.

O mais importante no relato de Livingstone é que este foi possivelmente o livro mais lido sobre a África pelas elites europeias em meados do século XIX, junto com os posteriores de Stanley. Desse modo, essas poucas palavras sobre o Kongo cativaram o imaginário e interesse de muitos interessados na empreitada colonialista europeia em África. O Kongo passou a ser pensado como um lugar mais fácil de se civilizar e cristianizar, por já ter relações históricas com o cristianismo. As ruínas das antigas igrejas romantizaram o lugar, e, como apontou Livingstone, se mostravam como um elo perdido do passado cristão esperando ser retomado pelos europeus. Assim, não é por acaso que S. Salvador foi o lugar escolhido para abrigar uma das primeiras missões protestantes da África Central em 1879. O industrial de Leeds (Inglaterra), Robert Arthington, apoiou a iniciativa com uma doação de 5,000 libras para a Sociedade Batista Missionária (BMS), com a finalidade de fundar uma missão na cidade (Arthington apud Bentley, 1900: 58-59):

Há uma parte de África (...) que tem por longo tempo me chamado a atenção, com muito desejo que a benção do Gospel possa ser dada a ela. Está no país Congo, um velho reino: uma vez possuiu, de fato, uma medida de civilização, e, com algum limite, era instruído nos exteriores da religião Cristã. (...) É para o Rei do Congo, e as comunidades existentes da antiga civilização cristã romana agora decaídas, em São Salvador, do país chamado Congo, que eu tenho há tanto tempo e tão fortemente desejado enviar (...) a Palavra de Deus, e dar a eles na sua própria língua, para nunca serem esquecidas, as palavras de Jesus e Seus apóstolos.

Para além dos interesses civilizatórios e religiosos, a missão possuía um fim político claro de buscar uma maior presença britânica na região, e, dessa forma, ganhar legitimidade em suas demandas políticas com relação à bacia do rio Congo. Tais demandas estavam imersas em um contexto de forte expansão colonialista das potências europeias. Territórios por todo o mundo foram avidamente cobiçados e invadidos, vistos como essenciais para a construção de impérios e fontes de exploração de matérias primas necessárias ao desenvolvimento industrial. O norte de Angola não escapou deste contexto e foi, assim, mais um palco das disputas imperialistas. 
Com o início desta missão religiosa da BMS, cita-se diversos trabalhos etnográficos sobre a cidade, produzidos pelos missionários presentes na missão (Bentley, 1900; Weeks, 1914; Johnston, 1910; Lewis, 1908). O movimento por parte dos britânicos foi visto com muito temor pelos portugueses. Em um momento em que as potências europeias rapidamente invadiam e buscavam territórios africanos, Portugal se encontrava ameaçado. Rapidamente, o governo lusitano incitou uma resposta para contrabalançar a presença inglesa na região. O Bispo de Angola, na época, D. José Netto, organizou uma missão político-religiosa, nas palavras de Barroso (1888-1889: 167), para “(...) que restaurasse a nossa influência combalida pelas intrigas de estrangeiros, pouco escrupulosos e sobretudo pouco reconhecidos”. Resultado dessa empreitada foi o estabelecimento de uma missão católica em 1881, e diversas publicações e registros foram feitos por uma série de viajantes portugueses que passaram pela cidade. Em um momento de tensão colonial, a presença portuguesa com a Missão seria chave para garantir as pretensões territoriais lusitanas no congresso de Berlim (1884-1885).

\section{A Paisagem COlonial Portuguesa de SÃo Salvador do CONGO}

Partimos agora para entendermos de forma sumária a configuração da paisagem colonial de São Salvador para os portugueses. O conceito de paisagem já está consolidado dentro da bibliografia arqueológica, e existe centenas de referências e trabalhos que o utilizam para as suas análises. Suas primeiras aplicações remontam a chamada "arqueologia do lugar" de Binford (1982) e outros processualistas. Desde então, como forma de refinar a análise, de acordo com Silva (2013: 30), “os lugares assim como as paisagens passaram a ser entendidos como significativos, adjetivados de várias maneiras (p.ex. sagrados, perigosos, tradicionais, culturais) (...)".

Dentre as muitas adjetivações, que não são fechadas em si, mas refletem perspectivas próprias dos autores, escolhemos o conceito de paisagem construída de Knapp e Ashmore (1999) como guia para a análise da paisagem de São Salvador do Congo. Segundo os autores, a paisagem construída é aquela feita especialmente por populações sedentárias, que (Knapp \& Ashmore, 1999: 10) “(...) estruturam suas paisagens mais obstrutivamente, edificando jardins físicos, casas e vilas na terra, geralmente próximos a alguns marcos naturais notáveis”.

Antes de tudo, o lugar (assim como a paisagem) é sobretudo uma questão de escala analítica e com fronteiras fluídas e variantes conforme as diferentes experiências. Tilley (2004: 25) afirma que "Lugares alojam-se na paisagem, e suas fronteiras não podem geralmente ser estritamente definidas.” Ingold (2000: 192) acrescenta “(...) então o lugar é a união de um significado simbólico com um delimitado bloco da superfície terrestre”, sendo que essa junção se dá pela experiência.

Segundo estes autores, a partir de uma abordagem fenomenológica, o corpo é responsável por medir esta vivência com o ambiente, sendo parte central do seu caráter: "Lugar deve seu caráter às experiências que fornece para aqueles que gastaram tempo lá - para as vistas, sons e mesmo cheiros que constituem seu ambiente específico”. Estes lugares não existem sozinhos, isolados, mas são vividos e experimentados em relação a outros lugares e a uma paisagem: “(...) um lugar na paisagem não está cortada do todo, seja no plano das ideias ou da substância material. Ao invés, cada lugar corporifica o todo em um nexo particular dentro dele, e neste respeito é diferente de cada outro". 
O que chamamos de paisagem colonial de São Salvador do Congo, então, é formada por diversos lugares significantes, formados principalmente por vestígios materiais da presença portuguesa na cidade, ou seja, construções em pedras e os significados atribuídos a elas. Dessas edificações, destaca-se as igrejas e edifícios adjacentes, que serão abordadas neste texto, e, sem dúvidas, o lugar mais importante desta paisagem colonial portuguesa na cidade são as ruínas da antiga Sé catedral. Refletindo sobre a importância da arqueologia da paisagem em pesquisas da África Atlântica, Kelly \& Norman (2007: 173) afirmam:

Arqueologia da paisagem na África Atlântica direciona a criação social da paisagem com as complexidades das localidades que eram ligadas dentro de sistemas globais de distribuições e troca; e enquanto ela foca na influência de fatores externos ao continente, ela não pode negligenciar as tradições locais, cosmologias e histórias.

Nesse contexto apontado, e sem dúvidas no caso de São Salvador do Congo, não podemos nunca considerar a cidade como uma paisagem "vazia" antes da chegada dos europeus. Em outro espaço abordamos de forma sistemática as diferentes narrativas locais sobre a atual cidade de Mbanza Kongo (Máximo, 2017).

As construções na paisagem criam, significam e marcam as populações que vivem ao seu entorno. Estas paisagens são possuem crenças, visões de mundo, mitos e ideologias, que as têm como referencial, o que leva muitas vezes à busca pela sua reconstrução por grupos contemporâneos que tentam "congelar" o seu significado. De acordo com Knapp \& Ashmore (1999: 10) disso decorre o “(...) truncamento e empobrecimento do seu corpo vivente de memória, para uma ruptura em sua "biografia cultural", ou seja, a "longa interação entre pessoas e seu ambiente".

Esse "congelamento" carrega em si diversas questões importantes, entre elas, uma conotação política clara de qual passado deve ser considerado exemplar a ser escolhido e valorizado. É a proposta de “congelamento" do passado de São Salvador do Congo pelas elites colonialistas de Portugal que nos interessa neste estudo. Como bem aponta Dyke (2008: 276) “(...) monumentos e paisagens são caminhos materiais potentes através do qual arqueólogos podem acessar memória social no passado. Estudos de memória podem prover arqueólogos com uma janela inovadora através da qual pensar sobre criação, manutenção e transformação de poder e identidade.” Todas estas questões, principalmente as relativas as relações de poder, são ainda mais ressaltadas em um ambiente profundamente colonialista em que se encontravam as fontes consultadas (Díaz-Andreu, 2007; Trigger, 2004).

Neste trabalho temos o objetivo de entender a criação da paisagem colonial de São Salvador a partir dos textos produzidos pela elite colonial portuguesa. Nos servindo de farta bibliografia publicada, os utilizamos não como fonte secundária, mas como documentos de análise, reflexos do pensamento político sobre a cidade, apoiando-nos, dessa forma, em documentação histórica para analisarmos e entendermos a paisagem e o papel das ruínas arqueológicas dentro desta. 


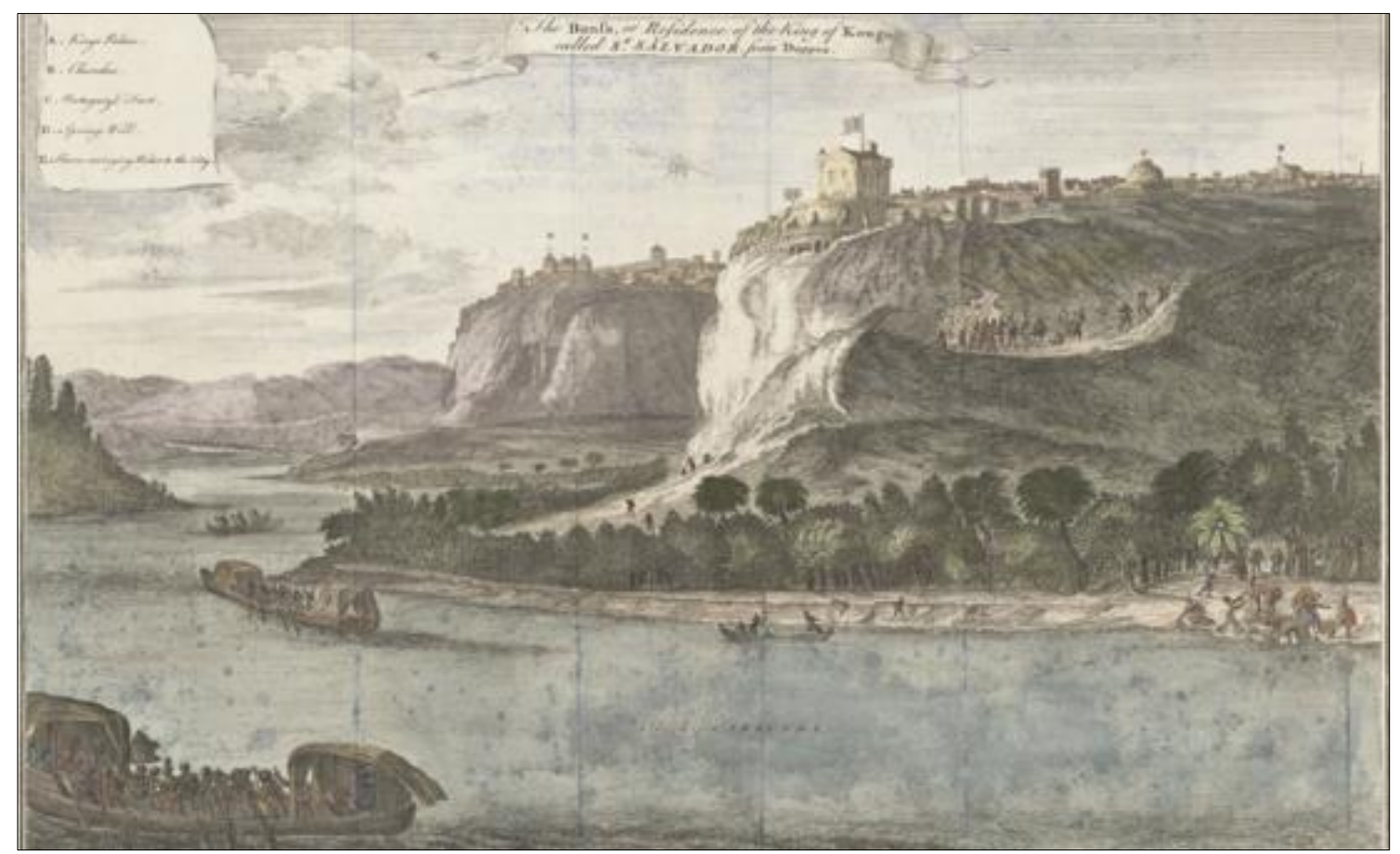

Figura 3: The Banza or Residence of the King of Kongo called S. Salvador. Fonte: Dapper, Olfert. Description de L'Afrique. Amsterdam: W. Waesberge, Boom et Van Someren, 1686. pp. 343-344

São Salvador era uma cidade pequena. Não para parâmetros regionais, mas para os europeus - e até principalmente para o seu próprio passado, em que cronistas descreviam uma grande cidade semelhante as europeias (De Maret, 2002). Se a expectativa da cidade era aquele da gravura do século XVII de Dapper (Figura 3), ou da descrição do século XVI de Duarte Lopes [1591] (1989), o visitante logo se frustrava: “(...) comparando o que nos diz Duarte Lopes da antiga povoação, com a actual, encontrâmos um abysmo de differença [...]" (Barroso, 1888-1889: 182).

Até a chegada das missões, o tamanho da cidade estava ligado a diferentes questões envolvendo disputas políticas relacionadas com o partido do rei beligerante, problemas com epidemias e até disputas culturais. Tanto que Zacharias (1858-1859), indagando aos locais sobre o porque de tantas casas abandonadas, “(...) disseram-me que era consequência do interregno: (...) porque muitos habitantes da cidade, temendo as guerras que há tais ocasiões, se ausentavam, e só voltavam depois de haver novo rei." Isto, é claro, quando estes se sentiam seguros para voltar e viver sob governo do novo soberano.

Em 1845, em meados do reinado de Henrique II, a cidade e seus subúrbios possuíam "(...) para cima de 3.000 cubatas, e pode avaliar-se em 18.000 habitantes, dos quais 3.000 pertencem à libata do rei.” (Castro, 1880). Em 1858, em pleno conflito bélico, a cidade se resumia em 350 a 400 casas, “(...) todas miseráveis, sem ordem, e em grandes distâncias umas das outras, com capim mui crescido pelo meio, e bananeiras, 
palmeiras e embondeiros, de sorte que nada se vê de um para outro lado.” (Cruz, 1858-1859). Já em 1879, após as guerras envolvendo a posse de D. Pedro V, a cidade possuía “(...) cerca de 200 casas de paus e palha, construída em um plateau (...)” (Johnston, 1910: 87), com amplas vistas para os arredores, como indicado pela citação de início, e um subúrbio "(...) de aproximadamente 50 casas ou mais, chamado Kilongo, na direção sudeste.” (Bentley, 1900: 193). Em 1881, 600 almas e, finalmente 3.500 em 1887 (Barroso, 1888 1889: 183). Essas casas de paus e palha acompanhavam os ritmos de crescimento e diminuição da população, e não somente da população nativa, pois os mesmos métodos de construção serviram para abrigar os diversos missionários e viajantes durante o século XIX.

A primeira igreja católica construída por Barroso (Figura 4), foi citada por Fragoso (1891: 37-38) no seguinte trecho: “(...) situada junto à casa da missão, é de pau a pique coberta de feltro, está pobre, mas decente, (...) não fica mal que ella esteja despida d'adornos".

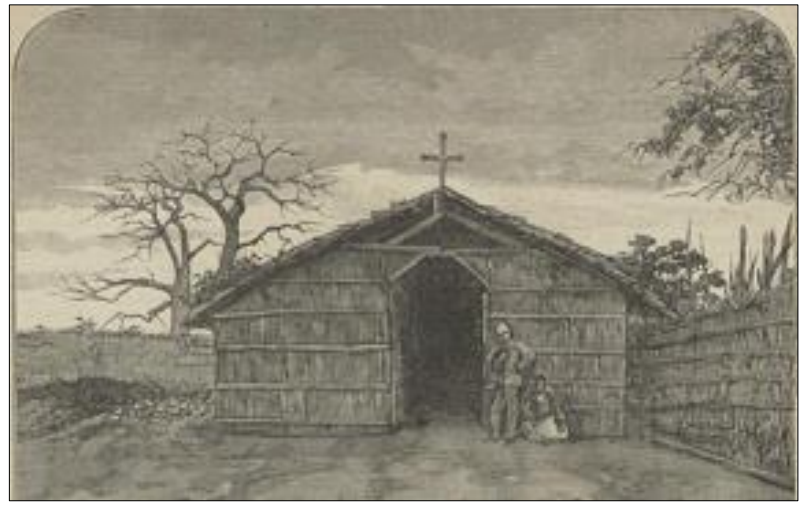

Figura 4: A Casa velha da missão portuguesa no Congo. Fonte: Revista O Occidente, nº159 de 1883.

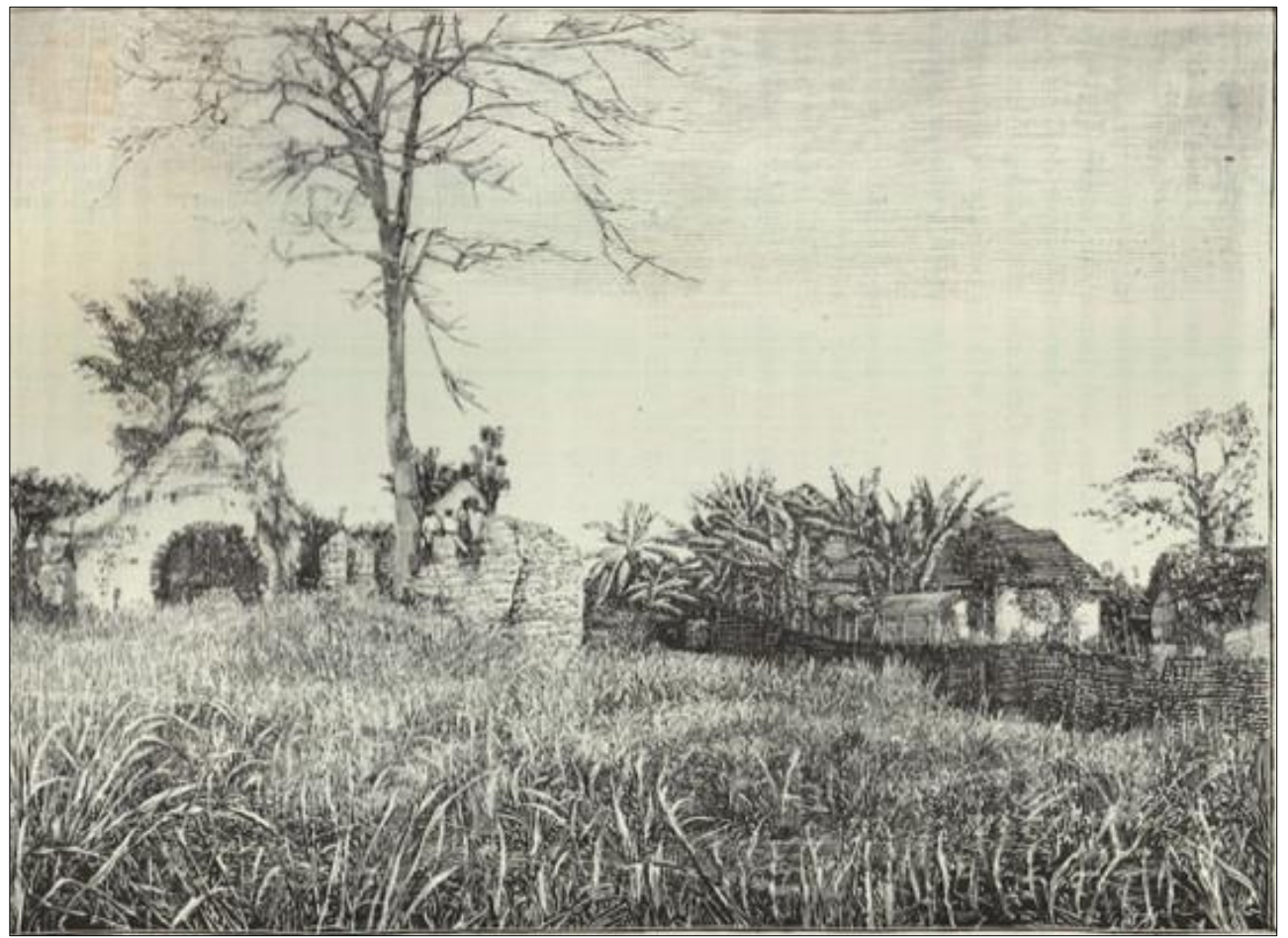

Figura 5: Ruínas de uma antiga igreja, São Salvador. Fonte: Lewis, 1902. 
$\mathrm{Na}$ cidade se encontravam as ruínas de igrejas (Figura 5), a muralha que circundava a cidade, o cemitério dos reis e nobres do Kongo, o palácio do Rei (lumbu ou banza) e uma crescente árvore, chamada de YalaNkuwu. Nesse palácio habitavam o Ntotila (rei do Kongo) e toda a sua família real, compreendendo, na época de D. Pedro V, “[...] suas 40 esposas, e sua própria casa, construída pelos portugueses em 1863” (Bentley, 1900: 141).

As casas tinham cercados que formavam um labirinto para ingressar. Nas palavras dos europeus, as partes externas dos cercados, em 1845, formavam as "ruas", “[...] que eram muito direitas, mas estreitas e não são formadas pelas casas, mas sim pelas estacadas, o que produz um efeito muito agradável á vista" (Castro, 1880).

Embaixo da árvore Yala-Nkuwu, eram realizadas as mais diferentes cerimônias, desde reuniões reais, audiências com o rei, e até culto religioso. Em outro trabalho analisamos com profundidade a história e papel da Yala-Nkuwu na paisagem ideativa para os povos kongo locais (Máximo, 2017).

Enquanto centro regional, na cidade eram organizadas feiras comerciais, e, a partir de 1880, feitorias estrangeiras se estabeleceram na cidade, de origens portuguesa, francesa e holandesa. As construções europeias se encerravam com o forte português. O forte foi construído após a coroação de D. Pedro V (1856), em um lugar apontado pelo tenente Zacharias. A estrutura militar se encontrava no topo da montanha, em frente ao grande desfiladeiro que termina no rio Lueji. Sua construção aconteceu em 1860, por um contingente de tropas enviadas do Ambriz para combater a revolta de D. Álvaro Dongo. Devido a este conflito, não conseguiram terminar a obra. Esse forte acabou sendo abandonado em 1866, e sua condição quando chegaram os visitantes posteriores era de deterioração, tendo sido, de acordo com Ribeiro (1882: 214), "Uma pena ter-se abandonado completamente a obra de fortificação que existe; tinha boas accommodações para uma guarnição de 50 praças, e com uns pequenos reparos seria muita aproveitavel para um destacamento."

A matéria-prima para a construção do forte proveio de duas fontes. Segundo Bentley, próximo a ele existia um forno, utilizado pelos soldados para queimar a cal para sua construção. Para conseguir as pedras necessárias, a guarnição recorreu às estruturas remanescentes das construções antigas, pois conseguir novas rochas para construir era muito difícil, sendo preciso, muitas vezes, andar quilômetros. Segundo Barroso (1888-1889: 182): “(...) a pedra de todas esses templos erguidos á gloria de Deus, serviu há um quarto de seculo, na epocha das ultimas expedições militares, para fazer um fortim octagono com angulos reintrantes e capacidade para 260 homens." Assim, enquanto fonte de material construtivo, foi feita uma alteração irreversível dos vestígios arqueológicos até então aparentes em superfície.

Esses templos "erguidos à glória de Deus" eram os vestígios das construções antigas, dos séculos XVI e XVII, que permaneciam na cidade, e não eram poucos. Consistiam em estruturas defensivas (uma grande muralha), construções ligadas aos antigos monarcas, como vários palácios, e principalmente estruturas eclesiásticas, como igrejas e o palácio episcopal. Comecemos com a muralha. Em 1845, ela tinha:

[...] de comprimento 150 a 200 passos [de 45 a 60 metros]; está na direcção N. a S., deste lado tem um torreão inteiro, e até com um reboque do meio para cima; com muito trabalho segui parte do alicerce desta muralha que continuava, e me pareceu que ela tinha duas portas na frente e no fundo, e duas pequenas janelas de cada lado (Castro, 1880). 
Tal muralha foi construída após a retomada da cidade dos Jagas, em finais do século XVI, para melhor protegê-la de novos invasores (sua representação aparece na gravura de Dapper - Figura 3). Após a batalha de Ambuíla (1665), a história dela é desconhecida. Sua forma ainda se encontrava visível para Castro, que conseguiu estimar seu comprimento e alguns componentes. Os outros viajantes, Zacharias e Sarmento, infelizmente não nos deixaram descrições sobre a muralha, que voltou a ser descrita na obra sobre Greenfell (Johnston, 1910: 87) e a de Bentley (1900: 180):

[...] nos subúrbios da cidade poderiam ser traçadas a construção das antigas muralhas, 15 a 20 pés de altura, construídos de grandes blocos de ferro misturado na hematita e pedaços de calcário.

A cidade de 1879 estava no sítio da cidade antiga, pois as muralhas podiam ser facilmente traçadas quando as queimadas anuais da grama limpavam o solo. Somente três partes da muralha sobravam, a maior delas sendo no terreno dado para nós pelo rei; outra parte estava a sudeste de nosso terreno, $\mathrm{e}$ outro atrás da catedral. A muralha era de 15 a 20 pés de altura por 2 pés e 6 polegadas a 3 pés de espessura; foi construída com argamassa de cal de grandes pedaços de hematita, com placas de calcário para agir como agregador.

Interessante é constatarmos que o principal referencial para Bentley concluir que a cidade da época estava no mesmo sítio da antiga eram as muralhas. Aparentemente, no período entre 1846-1879 não ocorreram mudanças bruscas em sua constituição.

Durante os séculos XVI e XVII foram construídas muitas igrejas na cidade, não sendo possível contabilizar um número preciso em relação a elas. Não sabemos nem sequer se a estrutura que se encontra na atual cidade, batizada de Sé Catedral desde o século XVI até hoje, foi realmente essa igreja e não outra, e, por isto, também não podemos saber a sua data de construção. Durante o século XIX, existiam, segundo os autores, 12 estruturas de igrejas remanescentes. Bentley (1887: 50), no entanto, aponta um número maior, "Entre a grama [...] existem ruínas de vinte e seis edificações, as quais são ditas terem sido igrejas, [...] e os sítios de vilas suburbanas e vilarejos." Castro (1880), em 1845, escreveu sobre as igrejas:

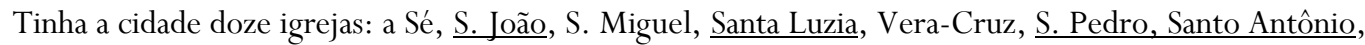
Nossa Senhora dos Remédios, Misericórida, S. José, Carmo e S. Tiago. (...) S. Miguel, que está quase no mesmo estado de ruína, é um pouco mais pequena [que a Sé]. Todas as outras apenas se lhe vê uma ou outra parede levantada, ou unicamente os alicerces.

Sarmento, em 1856 (1880: 56), fez também um registro das estruturas existentes:

(...) contámos admirados as ruinas de doze templos que deviam ter sido magestosos, e que em tempo haviam tido as seguintes invocações: Santa Sé Apostólica - S. Miguel, onde estã enterrado o rei D. Affonso I - Nossa Senhora da Conceição - S. Thiago, ou S. Jacob - Nossa Senhora do Rosário - $\underline{\text { S. João }}$ Baptista - S. José - Espirito Santo e as egrejas dos padres da Companhia, do convento dos Capuchinhos e da Santa Casa de Misericordia.

E novamente, em 1858, Zacharias (1858-1859):

(...) Igreja de S. Miguel - (...) Igreja da Sé - (...) templos de Nossa Senhora da Conceição, da BelaCruz, da Misericórdia, de Nossa Senhora do Rosário, de S. Tiago, S. João, S. José, e do Espírito Santo. 
Apenas há deles as ruínas no chão e um ou outro bocado de parede erguida! Todos também eram de pedra e cal.

Por fim, Barroso corrobora com a lista de Sarmento. Os outros autores, os protestantes ingleses, não fizeram uma nomeação dos templos, somente os citaram, e discutiram sobre a Catedral. A primeira pergunta que podemos fazer é como estes escritores sabiam qual das ruínas existentes correspondiam às igrejas descritas nas documentações históricas? Não existindo uma descrição documental precisa, é difícil podermos resgatar essa informação dos arquivos.

Barroso (1888-1889: 176) informa de uma pista, ao mencionar que era o rei que o informava das igrejas, “[...] e muitas vezes m'a repetiu o actual rei do Congo designando todos os logares d'estes templos.” Zacharias também nos escreve que muitas informações foram os locais que forneceram. Além disso, nossa principal fonte kongo é um texto publicado em 1926, chamado Princípios da Cristandade no Congo, intitulado pelos editores como "Uma fantasmagoria curiosa e histórica dum literato preto". O texto, único entre todos os consultados por ter uma autoria africana, é uma versão kongo da chegada dos portugueses e da conversão ao catolicismo, e, ainda, o autor faz uma relação das igrejas (Principios, 1926: 98):

As Igrejas são doze, a saber - A Santa Sé Appostólica - O Collegio dos Padres da Companhia - O Convento dos Capuchinhos - São Miguel onde está enterrado o Rei D. Affonso $1^{\circ}$ do nome e Christãndade - Nossa Senhora da Conceição - A Santa Casa de Misericordia - São Theago ou Jacob A Igreja de Vera Cruz - aonde se baptizou o Rei Dom João $1^{\circ}$ - Nossa Senhora do Rosario - São João Baptista: além de duas Igrejas que se achão nos Palacios do Rei aonde ouvem missa a saber: São José e Espirito Santo: todas estas Igrejas são antigas.

Ao final, como fonte de informações o autor anônimo cita um texto em posse do rei D. Henrique II (primeira metade do século XIX), Memórias das coisas antigas acontecidas n'este Reino do Congo e o modo com que nos veio a Christandade e os Bispos, que vinhão de Roma para governar este Bispado do Congo e destruídas com os Governos, datado de primeiro de janeiro de 1782. Tomando o texto de Sarmento e do anônimo, ainda comparando com o de Barroso, talvez devamos considerar esta versão a mais popular em São Salvador. Podemos então concluir que o conhecimento das ruínas era de domínio da monarquia (quiçá também dos habitantes de S. Salvador), que definiu e nomeou as ruínas de acordo com a sua versão da história. O importante aqui é pensarmos que os portugueses, desse modo, viviam em um lugar com essas igrejas, representando as marcas da presença portuguesa na região, e, entre essas edificações, a mais comentada foi a, também, mais preservada, a Sé Catedral (Figura 5 e Figura 6). Castro (1880) a descreve, em 1845 :

\footnotetext{
A sé ainda tem toda a capela mor, com uma escadaria de pedra que conduz ao altar, a capela do Sacramento, e a sacristia, que é muito pequena, conserva todas as paredes, mas que fica sobre uma porta que dá para o palácio do bispo está suspensa pelas raízes de uma árvore que nasceu no resto do edifício; tem parte de uma parede lateral do corpo da igreja; quanto ao mais só se descobrem os alicerces distinguido-se perfeitamente a porta por existirem em pé dois pedaços das ombreiras de pedra: a arquitectura é muito simples: um paralelogramo forma o corpo da igreja.
}

Sarmento é mais econômico e não comenta sobre a estrutura, somente deixa sua impressão sobre o passado da ruína. Zacharias também nos deixa informações pormenorizadas (1858-1859): 
Igreja da Sé - Ficava-lhe à esquerda o hospício de Santo Antônio, com o qual era ligada. Ainda se vê dois grandes torreões e um grosso muro, ao meio do qual estão paredes e arcos, em sacada, que indicam ter sido ali o vestíbulo do edifício. Os arcos conservam-se em bom estado. [...] Toda a frente das ruínas mede 250 metros. Da igreja, estão de pé as paredes da capela-mor, com o seu arco, este em perfeita conservação, e as duas sacristias laterais, com seus altares de pedra, como o altar-mor. Também existem as escadas do corpo da igreja para a capela-mor. [...] $\mathrm{O}$ adro do edifício era imenso: acompanhava-o em todo o comprimento, e estendia-se uns 50 passos para fora. Também está cheio de sepulturas, cobertas com as ruínas. Tudo era de pedra e cal.

E por fim Bentley (1900: 141), em 1879:

A catedral foi construída nos mesmos materiais [da muralha], e deve ter sido um prédio bom. Em 1879 a face oeste frontal tinha caído: o telhado tinha já desaparecido há bastante tempo, mas as outras paredes estavam razoavelmente preservadas, especialmente a capela-mor. O arco da capela estava um bem largo conjunto de pedras. $\mathrm{O}$ altar superior estava coberto com pequenas samambaias, mas em condições razoáveis. Havia uma capela a Nossa Senhora no lado norte da nave, e um vestíbulo do lado sul da capela-mor.

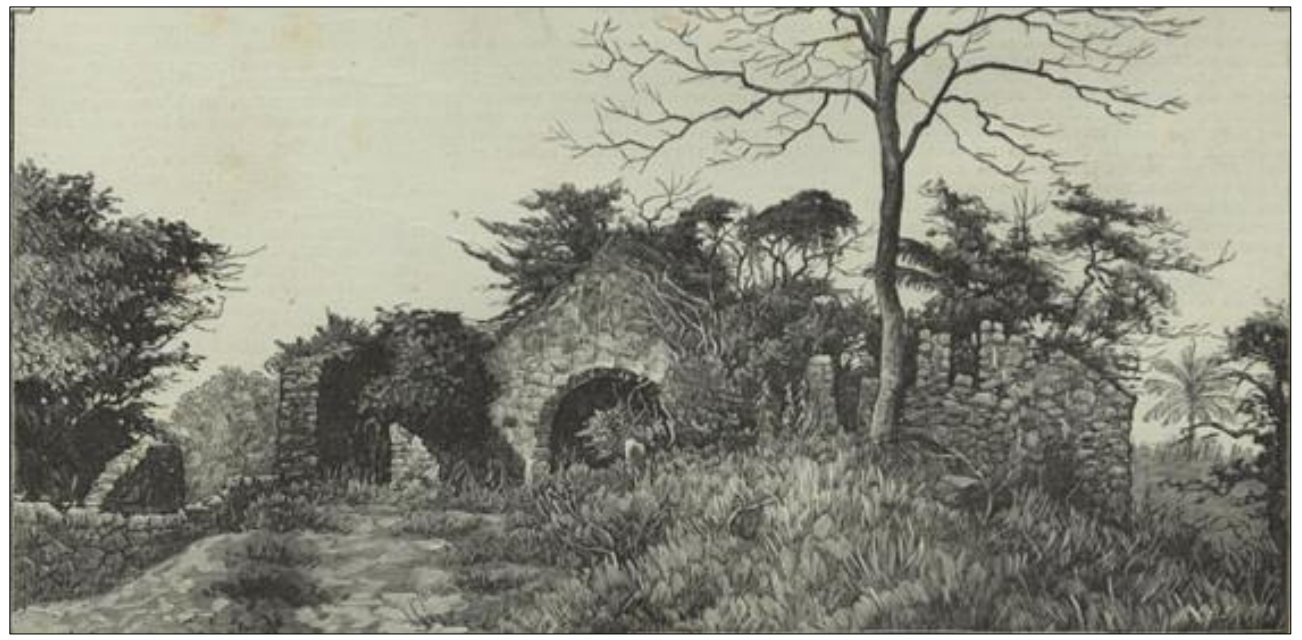

Figura 6: Ruínas de uma Egreja Portugueza (Cathedral), em S. Salvador do Congo. Fonte: Revista O Occidente, n $n^{\circ} 118,1882$.

$\mathrm{Na}$ cidade, havia ainda ruínas de um convento, de uma torre, cemitérios, hospedaria e do palácio antigo dos reis do Kongo. Quando os missionários cristãos chegaram para ficar e construir suas missões, eles logo se depararam com a mesma falta de pedras para construção que os soldados do forte tiveram anteriormente. Os batistas britânicos, que chegaram primeiro, resolveram este problema da mesma forma que a guarnição reutilizar as pedras das antigas estruturas, segundo Bentley (1900: 143):

Nós procedemos para construir nossa casa permanente de pedra, dentro da muralha da cidade; de fato, a velha muralha foi a fundação de nosso muro ocidental. As pedras para a construção foram coletadas e trazidas de ruínas na selva.

Eles construíram as casas e, depois, no final do século, também a igreja, assim como fez a missão católica. Os portugueses, reivindicando posse das ruínas desde a época de Castro, com os acordos de Henrique II, já mencionavam reconstruir as igrejas com o intuito de voltarem a ser ativas. Zacharias e Ribeiro também isso desejavam. Barroso, quando chamado a fazer a missão, tinha claro esse pensamento: 


\begin{abstract}
Alimentei sempre a esperança de que a antiga Sé poderia ser reedificada, ficando assim um bom templo sem demandar despezas extraordinárias; apenas, porém, se procedeu ao desentulho d'este logar, quasi completamente obstruído pelo arvoredo e hervagem, [...] fiquei plenamente convencido de que nada se podia fazer naquelle sentido; pois as paredes, exceptuando as da capella môr, estão por terra, e aquellas mesmas que existem de pé, acham-se em tal estado de ruína que seria demasiada temeridade tentar aproveitá-las. [...] Em vista d'estas medidas, a unica cousa que do antigo templo se pode utilisar, é a pedra que não é de pequeno valor n'este (sic) terra, onde escaceia. ${ }^{5}$
\end{abstract}

A construção do forte português, seguido posteriormente da construção das casas das missões, das igrejas batista e católica, da casa do residente administrativo e da nova casa do Rei do Congo, contribuiu de forma decisiva para a redução drástica do material arqueológico em superfície. Na época da chegada do administrador colonial chamado José Heliodoro de Faria Leal, que foi residente em São Salvador durante os anos de 1896 e 1913, já se observa uma situação das ruínas semelhante à atual. Seu texto, publicado em diversos fascículos durante os anos de 1914 e 1915 no Boletim da Sociedade de Geografia de Lisboa, constitui a principal fonte para o estudo da cidade no período.

Assim como os outros de sua época, Faria Leal foi a São Salvador buscando encontrar a cidade histórica, antiga (Faria Leal, 1914: 343):

Quando em fevereiro de 1896, vindo de Noqui, no rio Zaire, entrámos pela primeira vez em S. Salvador do Congo, procuramos debalde encontrar, ainda que fosse só em ruínas, os restos do antigo fausto da velha capital do reino do Congo, ficámos surpreendidos ao vermos a miserável povoação a que se dava o pomposo nome de cidade. Encontramos apenas um simples povoado gentílico, formado de cubatas, escondidas entre um matagal de bananeiras e de capim, de uma altura de mais de três metros nalguns pontos, e dessiminadas uma aqui, outra além, meia dúzia de casas de europeus, missionários ou comerciantes. Cruzavam o solo, em várias direções, restos de alicerces de pedra das antigas edificações religiosas, atestando a nossa incúria e decadência colonial nestas paragens. Da antiga ocupação e civilisação haviam desaparecido, moral e materialmente, quasi todos os vestígios. $\mathrm{O}$ arco da capela mór da antiga catedral, caboucos dos antigos conventos, as ruínas da fortaleza, eram as únicas relíquias do passado Congo.

S. Salvador era uma paisagem clara do passado lusitano. Leal e outros exploradores e colonialistas portugueses foram à São Salvador em busca da cidade histórica, mas se tornaram frustrados, pois "só" encontraram mato, bananeiras e algumas ruínas - a cidade ordinária. Os alicerces eram comuns e abundantes em toda zona, mostrando mesmo que houve uma ocupação intensa de casas de pedras no passado, sem dúvidas. No entanto a decisiva ação de reuso das pedras para outras construções iria contribuir definitivamente para a destruição das ruínas, tanto que no início do século XX a situação das ruínas se aproxima da atual.

\footnotetext{
${ }^{5}$ BARROSO, Antônio. Missão Portuguesa ao Congo. In: Oliveira \& Couto, 1917: 348.
} 


\section{SÃo SALVADOR NADA ORDINÁRIA: O LUGAR DO PODER E GLÓRIA DE PORTUGAL}

Em S. Salvador há traços indeleveis, que attestam o poder e gloria de Portugal; nos povos visinhos não se da o mesmo caso [...]. ${ }^{6}$

Como reconhece Barroso, não é todo lugar no reino do Kongo que possuía traços que atestavam a presença portuguesa e, portanto, serviam como lugares de legitimidade perante as disputas coloniais que aconteciam na época. São Salvador era um lugar chave. E era chave em dois sentidos, primeiro enquanto uma paisagem construída, palco principal da atuação portuguesa durante o período de expansão ultramarina em Angola, contendo lugares que ligavam o presente a esse passado glorioso, se remetendo aos grandes feitos do império português no século XVI. Em outro um segundo sentido, São Salvador era real e material, pois os marcos legitimadores estavam de certa forma presentes na cidade: as ruínas, a monarquia, enfim, a história materializada e redescoberta. Mesmo em estado de rápida destruição, nesse momento os portugueses se deram conta da importância da preservação das ruínas para suas propostas argumentativas frente às outras potências. Da mesma forma, os batistas foram se instalar na cidade para contestar a legitimidade portuguesa e tentar superar o fracasso dos portugueses.

Comecemos retomando o sexto postulado colocado por Cordeiro (1883: 33) sobre soberania: "Por documentos públicos, vestígios de edificações, tradições gerais de soberania, ou de suserania política.” São Salvador então foi pensada, visitada e habitada pelos portugueses nesses critérios. Tratemos primeiro da soberania política e posteriormente, os vestígios de edificações.

Essa (suposta) dominação de Portugal sobre o reino do Kongo teve início no final do século XV com a chegada de Diogo Cão e a posterior conversão de Nzinga-a-Nkwu:

Um mez depois de ali chegar [Diogo Cao], a expedição entrava na Banza Real (hoje S. Salvador), cedendo ás instancias do mesmo Muene Congo, que dizia querer inciar-se na religião dos brancos, estreitar assim a sua amisade e estabelecer relaçoes commerciais com elles. Estabelecida a amisade com os portuguezes, foi Jovi [?], em 1493, o primeiro dos monarchas do Congo que a rei de Portugal prestou vassallagem [...] (Capello \& Ivens, 1886: 41).

A partir deste momento, a monarquia africana procurou de toda forma emular o seu suserano, dando assim provas de sua submissão e aceitação da civilização portuguesa:

[...] depois do descobrimento e estabelecimento dos Portuguezes n'aquelle Reino, refere que a supremacia d'estes era ali tão grande, que os Príncipes do Congo tinham não só tomado os nomes portuguezes e os títulos das diversas jerarchias da nobreza de Portugal, mas até os principaes senhores tinham adoptado o vestuario portuguez [...] (Santarém, 1855: 23).

O reinado de Afonso é um marco nessa relação com Portugal, sendo ele idolatrado pelos autores portugueses como aquele que soube reconhecer a civilização portuguesa. Depois dele, foi feito um tratado de vassalagem, reafirmado após a retomada da cidade dos Jagas. A ajuda militar do português Francisco da Gouvea é interpretada como parte desse acordo, em que o suserano deve proteger o vassalo, em troca o rei do Kongo D. Álvaro II, "[...] prestou nas mãos do Governador Francisco de Gouvea menagem e vassallagem por si, e por seus descendentes, como vassallo, e tributário dos Reis de Portugal” (Santarém, 1885: 30). A

\footnotetext{
${ }^{6}$ BARROSO, Antônio. Missão Portuguesa ao Congo. In: Oliveira\& Couto, 1917: 351.
} 
partir daí, "todos os reis do Congo juraram homenagem e vassalagem á Corôa de Portugal, ractificando-a em diversas epochas." (Pimentel, 1899: 24).

A história de Portugal na região é, desse modo, a da dominação política sobre o Reino do Kongo. Importante ressaltar que essa narrativa foi duramente criticada pelos historiadores pós-coloniais, que denunciaram essa ação como uma invenção visando objetivos políticos ${ }^{7}$. Para os Portugueses, essa dominação aparecia nos vestígios das edificações e nos documentos históricos.

As antigas estruturas de pedra presentes na cidade foram automaticamente entendidas por parte dos autores portugueses como de construção lusitana, e, portanto, produto dos antigos exploradores, marcas “[...] que os nossos antepassados fizeram n'esta localidade em pró da religião e da civilisação d'este povo [...]" (Ribeiro, 1882: 214). Dessa maneira, as estruturas das ruínas são entendidas como resultado da conversão ao catolicismo - não visto como uma negociação, mas uma atitude unilateral de dominação, e do ato de conquista política portuguesa:

Relíquias d'este passado, resta-nos hoje a velha S. Salvador do Congo, a capital d'esse vasto império, com os restos das suas venerandas ruínas, pequena parte do que foi nosso, e sobre o qual passaram aventureiros nos tempos mais modernos, arrebatando-nos, [...] a purpura opulenta do nosso antigo nome e poderio n'aquellas vastas regiões (Pimentel, 1899: 19).

De todo este progresso religioso e dominação política o que resta? Encontram-se em S. Salvador, e por outras partes, muitas ruinas de templos. A capella mór da antiga sé do Congo ainda conserva o culto: é o ultimo reducto da civilização christã portugueza [...] (Pinto, 1888: 255).

Os portugueses sabiam da existência destas ruínas, e quando os britânicos chegaram na cidade e utilizaram as pedras antigas para construção (Figura 7), este fato gerou uma revolta dos lusitanos. Este ato foi interpretado por eles como uma afronta àquilo que mais estimavam: a paisagem portuguesa de São Salvador do Congo. Mesmo em estado de rápida destruição, neste momento os portugueses se deram conta da importância da preservação das ruínas para suas propostas argumentativas frente às outras potências.

Em nossos dias voltaram á tela os assumptos do Congo; não o indigena, mas o europeu, negou-nos desalmadamente os nossos direitos; direitos exarados em todos os documentos históricos, direitos attestados nos escombros das nossas velhas igrejas, direitos proclamados nas cruzes que implantámos nos confins dos sertoes (Barroso, 1888-1889: 234).

Os batistas construíram as suas casas usando o muro que existia anteriormente (Figura 8), se estabelecendo, segundo Pimentel (1899: 47) "[...] até com material dos antigos templos christãos [...]", fazendo "[...] pura missão política de derrancamento e de desnacionalisação, e perturbadora da evangelisação católica”.

No entanto os batistas não deixariam sem resposta os ataques portugueses. No ambiente de grande rivalidade e competição entre as potências coloniais, os britânicos buscaram contestar os argumentos

\footnotetext{
${ }^{7}$ A situação do reino do Kongo nunca foi a de vassalagem com relação à Portugal, e os portugueses do século XIX saberiam (sabiam?) disto se lessem os documentos antigos. Por exemplo, em um apontamento, o embaixador do Reino do Kongo em Madrid, em 1607 esclarece a situação política dos dois reinos: "El Rey do Congo dom Álvaro [...] e posto que diretamente não é vassalo de V. Majestade [Rei Felipe III], está todavia debaixo de sua real proteção e obediência: enviou a V. Majestade a dom Garcia Baptista por seu Embaixador[...]" Carta para Felipe III, 31/03/1607 In: BRÁSIO, Antônio. Monumenta Missionária Africana. Lisboa: Agência Geral do Ultramar. vol. 5, 1955. p. 280.
} 
lusitanos, relembrando-os de sua profunda relação com o tráfico de escravos. Eles apontam que as construções em São Salvador não eram obra dos portugueses, mas sim da política dos antigos reis de escravizar a população. Estes chefes locais faziam emboscadas em aldeias vizinhas, apreendendo a população e enviando para as capitais regionais. De lá, "[...] aqueles que permaneciam seriam deportados para a capital, forçados a construir lá, enquanto muitos seriam vendidos para comerciantes de escravos na costa" (Bentley, 1887: 50$)^{8}$. Ou seja, para Bentley, não há só nobreza na construção destes edifícios, mas também a marca desse passado escravista. Para o autor, as ruínas não eram a glória de Portugal nem símbolo da civilização, mas sim o contrário, "as tristes relíquias de um fracasso", de que não conseguiram cristianizar o Kongo.

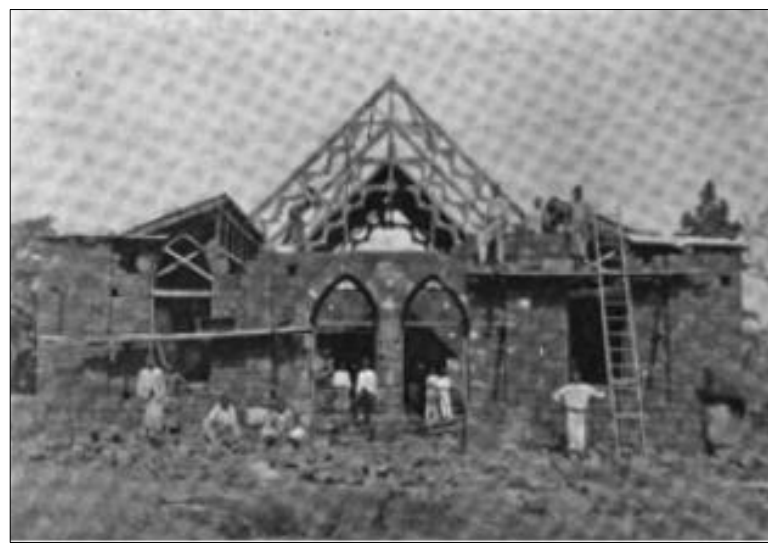

Figura 7: Construção da nova capela da missão. São Salvador do Congo. (Bentley, 1900).

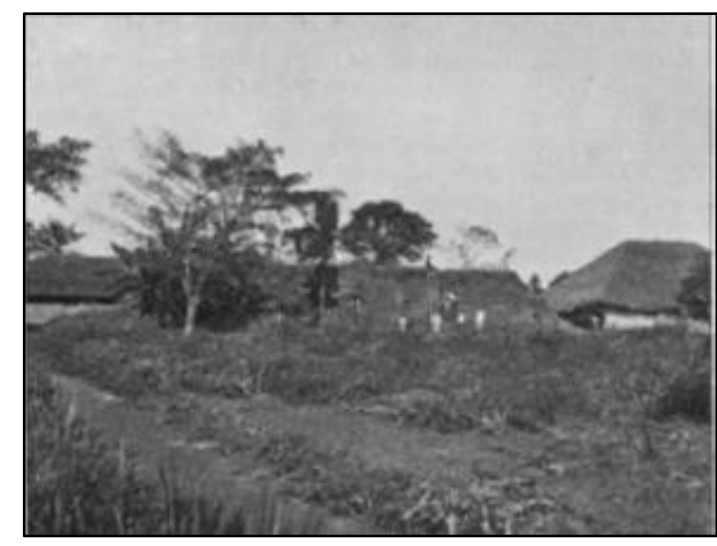

Figura 8: A ultima parte do muro do convento (Lewis, 1902).

Para fins de considerações finais, apresentamos o documento que teve a maior importância política para os portugueses, o Memorandum: A questão do Zaire e os Direitos de Portugal, de 1883, produzido pela Sociedade de Geografia de Lisboa, contendo os principais argumentos coloniais e cristalizando a paisagem de São Salvador do Congo para os portugueses da época. Esse texto tinha como objetivo revolver as pendências jurídicas sobre o domínio da foz do rio Zaire (Congo), que era alvo de intensa disputa pelas principais potências da época. Portugal, temendo instabilidade jurídica e uma perda de territórios, buscou compilar seus direitos de posse da região para apresentar ao Congresso de Berlim.

Esse congresso, vale ressaltar, foi fruto direto - dentre outras coisas - da disputa pelo rio Zaire (Congo). O texto publicado em 1883 foi composto para sumarizar os diferentes trabalhos feitos até então, padronizando-os em um discurso que legitimasse os direitos portugueses no Congo. Podemos pensar que esse foi o trabalho que Portugal levou para defender sua posição na conferência de Berlim sobre os conflitos na bacia do Rio Congo.

O principal ator da Sociedade Geografia de Lisboa (SGL), Luciano Cordeiro, era o seu secretário perpétuo e historiador, e esta publicação corresponde muito ao seu pensamento. O texto é divido em três partes, de acordo com os três princípios que regem "A soberania d'um Estado culto sobre qualquer território que elle declara pertencer-lhe [...]" (Sociedade, 1883: 3). São esses: a) Descoberta, b) Posse, c)

\footnotetext{
${ }^{8}$ O também missionário Lewis (1908: 591-592), também corrobora com a mesma ideia: "A antiga civilização de São Salvador se deve inteiramente ao comércio de escravos e dos Portugueses. Escravos esperando para serem enviados para a costa eram empregados a quebrar pedras, construir palácios, igrejas (...)”.
} 
Reconhecimento. Partindo desta divisão, seguem-se 122 postulados em que a SGL reivindicou os direitos portugueses na bacia do rio Congo.

Na primeira parte, o Padrão (marco de pedra colocado no final do século XV na foz do Rio Zaire), junto com a descoberta do Rio Zaire e a cidade de São Salvador, era um dos pontos centrais, representando a descoberta e soberania dos portugueses na foz do rio Congo. Esses lugares foram revelados por Diogo Cão, “[...] a sciência e a civilisaçao christã , [...] inici[ando] [...] a áspera e gloriosa campanha de exploração interior da África Equatorial” (Sociedade, 1883: 10).

$\mathrm{Na}$ segunda parte, a posse foi resultado da ação portuguesa junto ao Rei do Kongo, culminando na vassalagem deste: “[...] Affonso I, e que devendo o throno ao auxílio dos portuguezes, n’uma carta ao rei de Portugal, em 1512, expressa e formula terminantemente a sua vassalagem e dependencia.”, e a presença portuguesa em S. Salvador, “[...] estabeleciam-se auctoridades regulares em S. Salvador,” (Sociedade, 1883: 23) comprovada pelos documentos históricos, e nas provas materiais, "[...] fundando fortalezas, edificando egrejas ou estabelecendo feiras(..)” (Sociedade, 1883: 13-14). Na terceira parte, o reconhecimento de posse do Kongo é levantado com relação ao Vaticano e comenta-se sobre as disputas envolvendo o Ambriz e a vitória diplomática portuguesa.

Com este arcabouço teórico-argumentativo, Portugal partiu, em novembro de 1884, para participar da Conferência de Berlim, levando seis delegados, entre eles, Luciano Cordeiro. O resultado foi controverso, com parte dos autores aceitando as condições de Portugal e ficando satisfeitos com as deliberações, enquanto outros mais otimistas se decepcionaram com a perda da margem norte do Rio Zaire para o Estado Livre do Congo.

A partir da perspectiva apresentada defendemos que as ruínas de São Salvador e as relações históricas entre Portugal e o Reino do Kongo foram centrais para que Portugal controlasse a margem sul do Rio Zaire, na época, fonte de grande discórdia diplomáticas pelo seu comércio e riquezas. Os diversos estudos analisados neste artigo corroboram com esta assertiva. Foi através da paisagem construída de São Salvador do Congo que elementos chaves foram identificados e defendidos junto às outras potências coloniais.

Por um lado, os missionários ingleses e exploradores buscaram se assentar e tentar reivindicar para si o legado “cristão" de São Salvador do Congo, pautados em apontar o fracasso das ações anteriores portuguesas em atingir o resultado de civilização, inclusive classificando as ruínas como monumentos da política escravista lusa em África. Por outro lado, os lusitanos, que até a chegada dos britânicos pouco se importaram com a cidade, se viram ameaçados e tentaram de todas as formas identificar as glórias de sua presença em São Salvador. Essas glórias não estavam na cidade que eles encontraram no século XIX, uma urbe em ruínas e esvaziada, mas sim nos vestígios materiais das construções antigas e na narrativa de submissão política da monarquia kongo, principais fundamentos da paisagem colonial portuguesa de São Salvador do Congo.

De uma forma geral, as ideias e interpretações consolidadas nesse período serviram de base para todo o debate historiográfico sobre a cidade e o reino do Kongo (Máximo, 2017: cap. 2). Os autores aqui citados, principalmente os ligados à Sociedade de Geografia de Lisboa, se tornaram cânones sobre o pensamento 
colonial português - e mais especificamente sobre a história do Reino do Kongo e da cidade de São Salvador, tendo importantes ressonâncias futuras.

Com a posse definitiva do território, e, portanto, um reconhecimento por parte das outras potências do legado português na paisagem construída colonial de São Salvador, o Estado Português passou a preservar o local. A paisagem serviu de base para toda a discussão envolvendo os projetos de tombamento, que viriam a ser feitos nos séculos XX e XXI na cidade.

No projeto de tombamento do núcleo histórico de São Salvador do Congo como monumento nacional português em 1957 é clara a ligação com a paisagem do século XIX:

As antigas ruínas da Sé de S. Salvador do Congo, que, como ruínas se encontram em razoável estado de conservação, merecem ser defendidas e valorizadas, por se tratar de um monumento de alto significado histórico e religioso a que está ligado a fundação do primeiro Bispado de S. Salvador no Congo, em 1596, por Bula do Papa Clemente XIII, e ainda, porque, naquele local teria sido levantada, antes, pelos portugueses, a primeira Igreja ao Sul do Equador. Conservando a estrutura geral da planta com a Capela-mór e arco Triunfal, frestas e demais elementos com salientadas características das construções dos fins do nosso século XVI, deve considerar-se como um evidenciado padrão da nossa ação civilizadora.

No tombamento, é retomado pelo Estado Português o lugar Catedral como uma parte de um todo colonial português, símbolo de toda história e legado colonial, parte central da paisagem portuguesa na África. O catolicismo é o agente central do processo civilizatório e está intimamente relacionado com a própria fundação da cidade, negando qualquer tipo de importância e valor ao passado pré-cristão da urbe.

O mais surpreendente é constatar que mesmo após a independência de Angola em 1975 esta paisagem construída portuguesa ainda persiste junto às elites, desta vez não mais as coloniais, mas do Estado Angolano. No projeto de tornar a cidade como patrimônio mundial da UNESCO, a paisagem colonial aqui analisada permanece e foi revigorada com a candidatura, como afirma a ex-ministra da cultura de Angola, Rosa da Cruz e Silva (Mendonça, 2015):

(...) facto do nome desta cidade, antiga capital do Reino do Congo voltar a ecoar pelo mundo dada a sua candidatura a património mundial da UNESCO. (...) faz evocar e destacar a História de Angola e do Reino do Congo em particular, pelo contributo cultural que fomos dando ao mundo, e, do mesmo modo, do que dele recebemos numa relação de parceria, e intercâmbio, iniciada no Século XV após as primeiras expedições dos portugueses, pelo que incorporamos e expandimos. Desde o período da implantação do cristianismo e respectiva expansão, a cidade testemunhou a construção de 12 igrejas o que lhe valeu o título de Kongo dya Ngunga, o ensino das letras e da aritmética, foi uma prática regular. Propunham-se os reis do Congo transformar o Congo num estado cristão, pelo que a adopção de determinados aspectos dos valores europeus revelam essa capacidade de receber mas também de dar.

Novamente o passado cristão é visto com orgulho e como fundamental dentro do processo de valorização do passado, sendo, inclusive, escolhido pelo Estado de Angola como elemento definidor do projeto de patrimônio mundial da UNESCO. A paisagem colonial portuguesa, assim como muitas outras marcas coloniais, permanece ainda viva e atuante na sociedade angolana. 


\section{AGRADECIMENTOS}

Gostaria de agradecer ao crucial financiamento do CNPq para esta pesquisa. Também aos professores Ramon Sarrò, Marina Temudo e Patrício Batsikama pela ajuda nas pesquisas bibliográficas e documentais, e ao amigo Manuel Bivar por ter me acolhido de forma única em Lisboa. Também aos pareceristas que me ajudaram a perceber falhas e fizeram importantes apontamentos sem os quais o artigo certamente não teria a mesma relevância. 


\section{REFERENCIAS BIBLIOGRÁFICAS}

BARROSO, Antônio. 1888-1889. O Congo, seu passado, seu presente e seu futuro. Boletim da Sociedade de Geografia de Lisboa, 8 a Série, $n^{\text {os }} 3$ e 4

BASTIAN, Adolph. 1859. Ein Besuch in San Salvador, der Hauptstadt des Königreichs Kongo. Bremen: Druck und Verlag von H. Strack.

BENTLEY, Willian. 1900. Pioneering on the Congo. London: Religious Tract. Soc.

BENTLEY, Willian. 1887. Life on the Congo. London: The Religious Tract Society.

BINFORD, Lewis R. 1982. The archaeology of place. Journal of anthropological archaeology, v. 1, n. 1, p. 5-31.

BRÁSIO, Antônio. 1952. Monumenta Missionária Africana. Lisboa: Agência Geral do Ultramar.

CAPELLO, Hermenegildo; IVENS, Roberto. 1886. De Angola à contra-costa. Lisboa: Imprensa Nacional.

CASTRO, A. J. 1880. Roteiro da viagem ao reino do Congo. Boletim da Sociedade de Geografia de Lisboa, 2. ${ }^{a}$ Série, n. ${ }^{\circ}$ 2. Acesso em 14/07/2017. Disponível em: https://web.archive.org/web/20150409181213/http://arlindo-correia.com/161208.html

CAVAZZI DE MONTECUCCOLO, Giovanni Antônio. 1965. Descrição histórica dos três reinos do Congo, Matamba e Angola. Tradução, notas e índices pelo Pe. Graciano Maria de Leguzzano, introd. bibliográfica por F. Leite de Faria, Lisboa: Junta de Invest. do Ultramar.

CORDEIRO, Luciano. 1883. Portugal and the Congo. London: E. Stanford.

CRUZ, Zacharias da Silva. 1858-1859. Extracto de um relatório do chefe do concelho de D. Pedro 5. ${ }^{\circ}$. Boletim Oficial do Governo Geral da Província de Angola, n. 690 e 691 (1858); e n. ${ }^{\circ}$ 692, 695, 696, 701, 702, 710 e 711 (1859). Acesso em 14/07/2017. Disponível online em: https://web.archive.org/web/20150409133449/http:/ /arlindo-correia.com/020907.html

DE MARET, P. 2002. Urban origins in Central Africa: The case of Kongo. In P. Sinclair (Ed.), The development of urbanism in Africa from a global perspective (pp. 1-15). Uppsala: Uppsala Universitet, Institutionen för arkeologi och antik historia, Afrikansk och jämförande arkeologi.

DÍAZ-ANDREU, Margarita. 2007. A World History of Nineteenth-Century Archaeology. Nationalism, Colonialism, and the Past. Oxford: Oxford University Press.

FARIA LEAL, José Heliodoro. 1914. Memórias D'África. Boletim da Sociedade de Geografia de Lisboa, nº10, 32ª série.

FRAGOSO, Henrique M. 1891. Diário de uma viagem do Ambriz a S. Salvador do Congo. Luanda: Typ. Luso-africana.

HEINTZE, Beatrix. 2010. Exploradores Alemães em Angola (1611-1945). Apropriações Etnográficas entre comércio de escravos, colonialismo e ciência. Frankfurt am Main: Frobenius Institut.

HILTON, Anne. 1985. The Kingdom of Kongo. Oxford: Clardon Press.

INGOLD, Tim. 2000. The temporality of the landscape. In: INGOLD, Tim. The perception Of the environment. Essays in livelihood, dwelling and skill. London/New York: Routledge.

JOHNSTON, Harry. 1910. George Grenfell and the Congo. New York: Appleton \& Co. Vol. 1.

KELLY, K. \& NORMAN, Neil. 2007. Historical archaeologies of landscape in Atlantic Africa. In: HICKS D. (Ed.), MCATACKNEY, L. (Ed.), FAIRClOUGH, G. (Ed.). 2007. Envisioning Landscape. New York: Routledge.

KNAPP, B. \& ASHMORE, W. 1999. Archaeological Landscapes: Constructed, Conceptualized, Ideational, in: KNAPP, B; ASHMORE, W; Archaeologies of landscape: contemporary perspectives. Oxford: Blackwell Publishing.

LEWIS, Thomas. 1902. The Ancient Kingdom of Kongo: Its Present Position and Possibilities. The Geographical 
Journal, Vol. 19, No. 5. (Maio)

LEWIS, Thomas. 1908. The Old Kingdom of Kongo. The Geographical Journal, Vol. 31, nº 6.

LIMA, José Joaquim de Lopes. 1845. Descobrimento e posse do reino do Congo pelos Portuguezes no seculo XV, sua conquista por as nossas armas no seculo XVI, e successos subsequentes até o começo do seculo XVII. Lisboa: Imprensa Nacional.

LIVINGSTONE, David. 1861. Livingstone's travels and researches in South Africa. Philadelphia: J. W. Bradley.

MARQUES, João Pedro. 2006. A Ocupação do Ambriz (1855): Geografia e Diplomacia de uma derrota Inglesa. Africana Studia, $\mathrm{n}^{\circ} 9$.

MÁXIMO, Bruno Pastre. 2017. Um lugar entre dois mundos: paisagens de Mbanza Kongo, 312p, Dissertação (Mestrado) - Museu de Arqueologia e Etnologia da Universidade de São Paulo, São Paulo.

MENDONÇA, J. L. 2015. Mbanza Congo mais próxima do património mundial da UNESCO. Portal de Angola, 17 fev. 2015. Disponível em: <https://www.portaldeangola.com/2015/02/mbanza-congo-mais-proxima-dopatrimonio-mundial-da-unesco/>. Acesso em: 20 out. 2016.

MONTEIRO. Joachim John. 1876. Angola and The River Congo. New York: MacMillan and Co.

OLIVEIRA, Mario Antônio Fernandes de; COUTO, Carlos Alberto Mendes do. 1971. Angolana, (Documentação sobre Angola). Luanda: Instituto de Investigação Científica de Angola e Lisboa: Centro de Estudos Históricos Ultramarinos, vol. 2.

PELISSIER, Rene. 1986. História das Campanhas de Angola: resistência e revoltas (1845-1941). Lisboa: Editorial Estampa, Vol. 1.

PIGAFETTA, Filippo, LOPES, Duarte. 1989. Relação do reino do Congo e das terras circunvizinhas. Lisboa: ALFA, [1591].

PRINCIPIOS da Cristandade no Congo. 1926. Missões de Angola e Congo. Braga, ano VI, número 5.

RIBEIRO, João Carlos. 1882. De Noqui a S. Salvador. Boletim da Sociedade de Geografia de Lisboa, $3^{\mathrm{a}}$ Série, $\mathrm{n}^{\circ} 4$.

SANTARÉM, Manuel Francisco, Visconde de. 1855. Demonstração dos direitos que tem a coroa de Portugal sobre os territórios situados na costa occidental d'Africa entre o $5^{\circ}$ grau e 12 minutos e o 8 de latitude meridional e por conseguinte aos territorios de Molembo, Cabinda e Ambriz. Lisboa: Imprensa Nacional.

SARMENTO, Alfredo de. 1880. Sertões de África: apontamentos de viagem. Lisboa: Editor Francisco Arthur da Silva.

SILVA, Fabíola Andrea. 2013. Território, lugares e memória dos Asurini do Xingu. Revista de Arqueologia, [S.l.], v. 26 , n. 1, p. 28-41, jul.

SOCIEDADE DE GEOGRAFIA DE LISBOA. 1883. Memorandum: A questão do Zaire e os Direitos de Portugal. Lisboa: Fornecedores da Casa de Bragança, 1883.

SOUZA, Marina de Mello e. 2002. Reis negros no Brasil escravista: história da festa de coroação de Rei Congo. Belo Horizonte: Editora UFMG.

STANLEY, Henry M. 1885. The Congo and the founding of its free state: a story of work and exploration. New York: Harper \& Brothers.

STANLEY, Henry M. 1878. Through the Dark Continent. New York: Harper \& Brothers Publishers.

THORNTON, John K. 1983. The Kingdom of Kongo: Civil War and transition 1641-1718. Madison: Univ. of Wisconsin.

TILLEY, Christopher Y. 2004. The Materiality of Stone. Oxford: Berg.

TRIGGER, Bruce G. 2004. História do pensamento arqueológico. Tradução de Ordep Trindade Serra. São Paulo: Odysses Editora. 
BRUNO PASTRE MÁXIMO

TUCKEY, James H. 1818. Narrative of an expedition to explore the River Zaire, usually called the Congo, in South Africa. London, Murray.

WEEKS, John. 1914. Among the Primitive Bakongo. Seeley: Service and Company. 